\title{
BISON SELECTION OF PRAIRIE DOG COLONIES ON SHORTGRASS STEPPE
}

\author{
Jennifer G. Chipault ${ }^{1,2,4}$ and James K. Detling'2,3
}

\begin{abstract}
Aвstract.-American bison (Bison bison L.) preferentially use black-tailed prairie dog (Cynomys ludovicianus L.) colonies over uncolonized range in the mixed-grass prairie of North America. To assess bison use of prairie dog colonies in a different ecosystem, the shortgrass steppe, this study was conducted at the Vermejo Park Ranch, New Mexico. Driving surveys were conducted in summer 2007 to determine the number of bison on and off prairie dog colonies in 2 pastures. Prairie dogs occupied $25.5 \%$ and $48.5 \%$ of the 2 pastures surveyed. Bison of both sexes used prairie dog colonies more than expected compared to a scenario of bison using colonies based on colony availability $(P<0.001)$. With the exception of bulls in one pasture, bison observed off-colony were more likely to be grazing than bison observed oncolony $(P<0.04)$. When selection of prairie dog colonies was assessed for only those bison observed grazing, bulls in both pastures and cows in one pasture used prairie dog colonies more than expected based on availability $(P \leq 0.001)$. Forage quality was superior on prairie dog colonies, with crude protein higher $(P<0.001)$ and acid detergent fiber lower $(P<0.001)$ in blue grama (Bouteloua gracilis [Willd. ex Kunth] Lag. ex Griffiths) collected on-colony than offcolony. Further studies under a variety of conditions are still needed, but selection for prairie dog colonies by bison at Vermejo, combined with findings from previous studies, suggests that during the growing season, bison and cattle (Bos taurus L.) might select prairie dog colonies over uncolonized range in both the northern and southern extents of North American grasslands.
\end{abstract}

Resumen.-El bisonte americano (Bison bison L.) utiliza preferentemente las colonias de los perritos de la pradera de cola negra (Cynomys ludovicianus L.) en lugar del hábitat no colonizado de las praderas mixtas de Norteamérica. Con el fin de analizar el uso de las colonias de los perritos de las praderas por el bisonte en un ecosistema diferente, la estepa de pastos cortos, este estudio se realizó en Vermejo Park Ranch, New Mexico. En el verano del 2007 se realizaron monitoreos desde vehículos para establecer la cantidad de bisontes que había dentro y fuera de estas colonias en dos pastizales. Los perritos de la pradera ocupaban el $25.5 \%$ y el $48.5 \%$ de los dos pastizales que se analizaron. Los bisontes de ambos sexos utilizaban estas colonias más de lo esperado, en comparación con la situación hipotética de que los bisontes utilizaban colonias según su disponibilidad $(P<0.001)$. Con excepción de los toros en uno de los pastizales, se encontró que era más probable que los bisontes observados pastaran fuera de la colonia que dentro de ella $(P<0.04)$. Cuando se evaluó la selección de las colonias de los perritos de la pradera por parte de los bisontes que se observaron mientras pastaban, los toros de ambos pastizales y las vacas de un pastizal utilizaron las colonias más de lo esperado, según la disponibilidad $(P \leq 0.001)$. La calidad en la búsqueda de alimentos fue superior en el caso de las colonias de los perritos de la pradera, donde el porcentaje de proteína cruda fue superior $(P<0.001)$ y el porcentaje de fibra detergente ácida fue inferior $(P<0.001)$ en la grama azul (Bouteloua gracilis [Willd. ex Kunth] Lag. ex Griffiths) que se recogió en mayor cantidad en la colonia que fuera de ella. Si bien es necesario realizar más estudios en distintas condiciones, la selección de los bisontes de las colonias de los perritos de la pradera en Vermejo, combinada con los hallazgos de estudios previos, sugiere que durante la temporada de cultivo, es posible que el bisonte y el ganado (Bos taurus L.) seleccionen estas colonias en lugar del hábitat no colonizado en las zonas del norte y del sur de los pastizales de Norteamérica.

Prairie dogs (Cynomys spp. L.) have pronounced effects on North American grassland ecosystems (Whicker and Detling 1988, Kotliar et al. 1999, Miller et al. 2000). As with many ecological processes, however, the influence of prairie dogs on their environment depends on a variety of factors, including grassland type, weather, and duration of prairie dog colonization. In general, there tends to be lower biomass yet higher crude protein concentration (Coppock et al. 1983a, Krueger 1986,
Holland and Detling 1990, Cid et al. 1991, Fahnestock and Detling 2002, Curtin 2008, Cheng and Ritchie 2006) and digestibility (Coppock et al. 1983a, Curtin 2008, Cheng and Ritchie 2006) of grass on prairie dog colonies compared to grass off-colony. Lower graminoid biomass on prairie dog colonies results from burrowing, intensive grazing, and clipping of unconsumed grass by prairie dogs and aids in detection of predators and in communication (Hoogland 1995). The higher crude

\footnotetext{
${ }^{1}$ Turner Endangered Species Fund, 1123 Research Drive, Bozeman, MT 59718.

${ }^{2}$ Department of Biology, Colorado State University, Fort Collins, CO 80523-1878.

${ }^{3}$ Natural Resource Ecology Laboratory, Colorado State University, Fort Collins, CO 80523-1499.

4E-mail: jgchipault@yahoo.com
} 
protein concentration and digestibility of grass on prairie dog colonies results from this ongoing cycle of defoliation, which maintains a younger average leaf age and induces greater nitrogen $(\mathrm{N})$ allocation to aboveground growth (Green and Detling 2000), and from greater N mineralization rates on prairie dog colonies (Holland and Detling 1990, Fahnestock and Detling 2002).

Because of the higher forage quality on prairie dog colonies, it is plausible that large ungulates such as domestic cattle (Bos taurus L.) and bison (Bison bison L.) would prefer to graze on colonies rather than on uncolonized range, especially during the growing season. Indeed, bison in northern mixed-grass prairies select for prairie dog colonies from spring through autumn (Coppock et al. 1983b, Krueger 1986). However, it is not known whether bison prefer prairie dog colonies in mixedgrass prairie because of the more pronounced effects of prairie dogs in that grassland type, or whether bison prefer prairie dog colonies regardless of grassland type. Differences in graminoid biomass and resilience might make prairie dogs' influence on their ecosystem not as prominent in the semiarid shortgrass steppe dominated by short-statured, aggregated grasses as in the more mesic mixed-grass prairie, which includes a suite of taller-statured grasses (Winter et al. 2002, Detling 2006a). There has been a lack of research on bison use of prairie dog colonies in shortgrass steppe (Detling 2006a, 2006b), but in a study of cattle habitat use in Colorado shortgrass steppe, cattle did not consistently select for prairie dog colonies during the growing season of a year with relatively high precipitation (Guenther and Detling 2003). In contrast, Davidson et al. (2010) cited unpublished data suggesting that cattle in a Mexican desert grassland preferentially grazed on prairie dog colonies. Similarly, cattle surveyed over 3 years (May through December) in the Oklahoma panhandle were positively associated with prairie dog colonies (Lomolino and Smith 2003).

The objectives of this study were to (1) determine whether bison preferentially graze on colonies of black-tailed prairie dogs $(C y$ nomys ludovicianus $\mathrm{L}$.) on semiarid shortgrass steppe as they do in more mesic grasslands and (2) determine whether forage quality is higher on these colonies than on the surrounding uncolonized areas.

\section{METHODS \\ Study Area}

We conducted this study at the Vermejo Park Ranch (hereafter "Vermejo"), a privately owned bison ranch in Colfax County, northern New Mexico. Vermejo encompasses 24,000 ha of shortgrass steppe dominated by blue grama (Bouteloua gracilis [Willd. ex Kunth] Lag. ex Griffiths). In summer 2007, 1300 adult bison (B. Coppedge, personal communication, February 2008) and $\sim 2000$ ha of prairie dog colonies (D.H. Long unpublished data) occupied the Vermejo grassland.

\section{Bison}

To assess bison use of prairie dog colonies, we surveyed 2 pastures ("West" [ $\sim 3045 \mathrm{ha}$ ] and "East" $[\sim 4110 \mathrm{ha}])$ via a variable-width transect by slowly driving a truck on ranch roads through the pastures (Fig. 1). Two survey routes, $\sim 8 \mathrm{~km}$ each, were driven 16 and 18 times between 26 May and 28 June 2007. Surveys commenced during the early growing season and ended when the bison were moved to other pastures. Surveys were usually performed at dawn or dusk when bison graze most actively (McHugh 1958). Start times and locations varied. One route passed through both pastures, whereas the other was fully within the East Pasture. Bison were restricted to one pasture or the other. Data were divided into West and East pastures after the surveys were complete.

We determined the viewshed by examining a topographic map while traveling survey routes. Because of riparian terrain, $3.4 \%$ of the area could not be seen from the road (Fig. 1) and was removed prior to analyses. The total viewshed was 3113 ha and encompassed part or all of 13 prairie dog colonies that ranged in age from 3 to $50+$ years $($ median $=7$ years; Fig. 1). On the basis of locations of the outermost active prairie dog burrows, the perimeters of these prairie dog colonies were mapped in autumn 2007 (D.H. Long unpublished data), and the percent of each pasture occupied by prairie dog colonies was determined.

When bison were observed during driving surveys, the truck's location was recorded and the distance and compass bearing to the animal(s) were obtained so that bison locations could be mapped in relation to prairie dog colonies and water sources. To ground-truth 


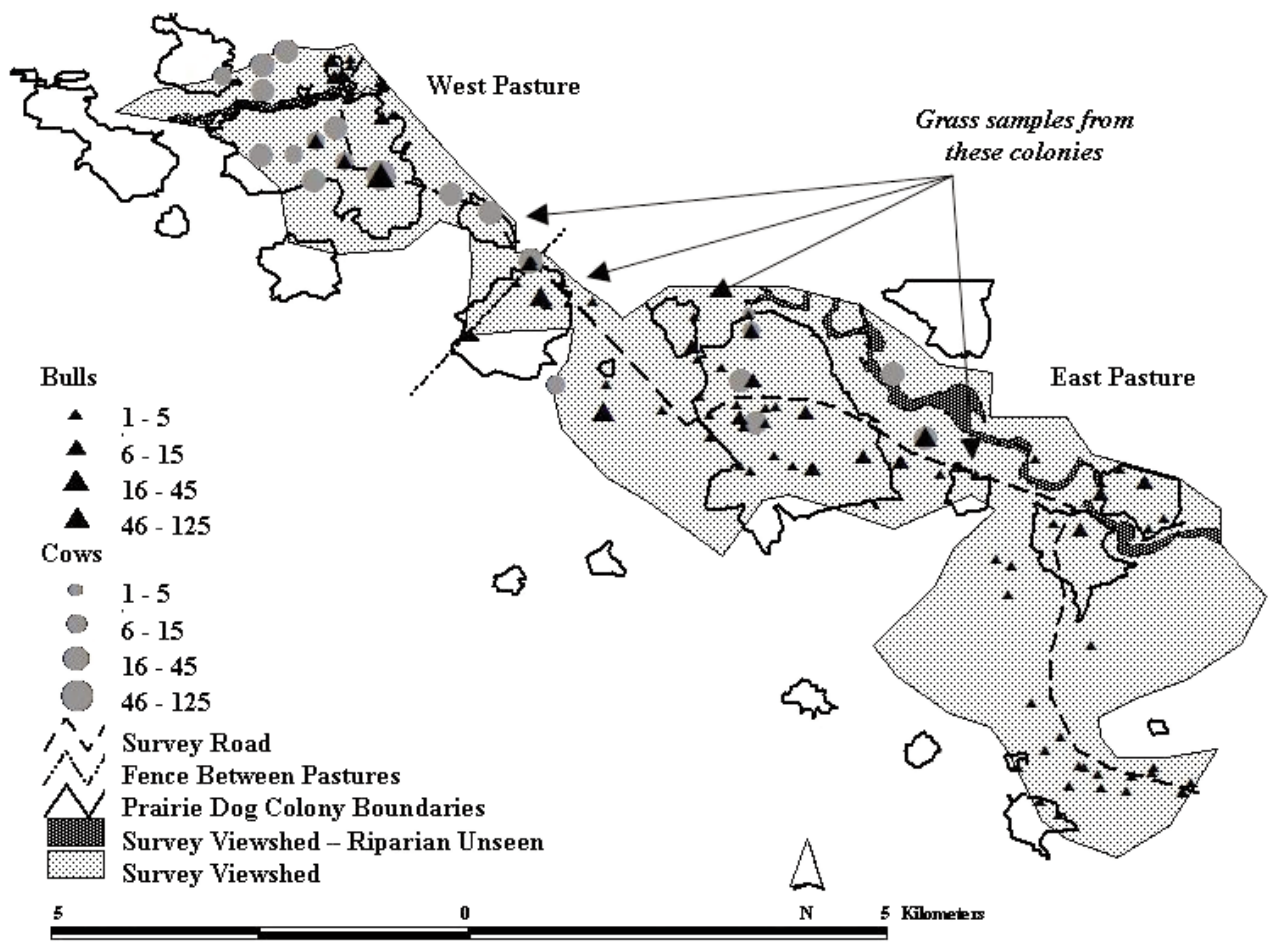

Fig. 1. Map of viewshed surveyed for bison at Vermejo Park Ranch, New Mexico, 26 May-28 June 2007. Size of bison symbols corresponds to number of bulls or cows observed in the group. Total viewshed surveyed $=3113$ ha, West Pasture $=610$ ha, East Pasture $=2503$ ha .

mapped data, we also noted in the field whether the bison were on or off a prairie dog colony.

Groups of bison were visually scanned to estimate numbers for age, sex, and behavior categories. Animals were classified as bull, cow, or calf, but calves were removed from the data set prior to analyses because they were not independent from their mothers. Because bison groups are fluid (Lott and Minta 1983, Van Vuren 1983, Krueger 1986, Schuler et al. 2006), all individual adults were considered independent. Bison behavior was classified as grazing or not grazing.

Using program $\mathrm{R}$ (version 2.8.1), $\chi^{2}$ goodness-of-fit tests were performed to evaluate the null hypothesis that bison used prairie dog colonies in proportion to their availability by pasture. These $\chi^{2}$ tests compared the number of bison observed on colonies to the number of bison that would be expected on colonies based on the percentage of the viewshed occupied by prairie dog colonies. Differences in frequencies of grazing on- and off-colony were also assessed using $\chi^{2}$ tests. Because our main objective was to determine whether bison preferentially graze on colonies, $\chi^{2}$ tests were also used to evaluate if the subset of bison observed grazing used prairie dog colonies in higher proportions than colony availability by pasture.

To ensure that bison were not selecting prairie dog colonies because colonies harbored sources of water, distances between bison observed on-colony and the nearest water source (natural or human-made) were compared to distances between bison observed off-colony and water. Data were assessed for normality at the $\alpha=0.10$ level, and subsequent Wilcoxon's rank-sum tests were performed in program $R$.

\section{Grass}

Paired samples of blue grama were collected on and off 4 colonies (Fig. 1) every other day during 3 periods in 2007: early (24 May-1 June), mid (24 June-2 July), and late (20-28 August) growing season. All 4 colonies sampled were created via prairie dog translocations in 2000 and covered 382, 62, 61, and 51 
Table 1. Bison selection of black-tailed prairie dog colonies on Vermejo Park Ranch, New Mexico $(n=1037$ total bison observed). Locations of bison were obtained during driving surveys performed 26 May-28 June 2007.

\begin{tabular}{|c|c|c|c|c|c|}
\hline & $n$ & $\begin{array}{l}\% \text { Pasture } \\
\text { colonized }\end{array}$ & $\begin{array}{l}\% \text { Bison } \\
\text { on-colony }\end{array}$ & $\chi^{2}(\mathrm{df}=1)$ & $P$ \\
\hline \multicolumn{6}{|c|}{ West Pasture } \\
\hline Bulls & 197 & 48.5 & 86.8 & 115.7 & $<0.001$ \\
\hline Cows & 433 & 48.5 & 60.7 & 26.0 & $<0.001$ \\
\hline Total & 630 & 48.5 & 68.9 & 104.9 & $<0.001$ \\
\hline \multicolumn{6}{|c|}{ East Pasture } \\
\hline Bulls & 267 & 25.5 & 62.2 & 189.0 & $<0.001$ \\
\hline Cows & 140 & 25.5 & 56.4 & 70.5 & $<0.001$ \\
\hline Total & 407 & 25.5 & 60.2 & 257.9 & $<0.001$ \\
\hline
\end{tabular}

ha in autumn 2007 (Fig. 1; D.H. Long unpublished data). Specific sampling sites were randomly selected within representative areas of blue grama, and new sites were selected on each sampling date. All aboveground material of 2 or 3 adjacent tufts of the caespitose blue grama were clipped near the base. Standing dead and senesced material was removed. Only samples of live grass were dried in paper bags for $>24 \mathrm{~h}$ at $55^{\circ} \mathrm{C}$. Samples were analyzed by ServiTech Laboratories (Hastings, NE). Total nitrogen concentrations (\% dry mass) were determined via sample combustion and then multiplied by 6.25 to obtain crude protein data. Percent acid detergent fiber (ADF), a factor inversely related to digestibility of forage, was determined by boiling grass samples in acid detergent solution and weighing the residue.

Blue grama was chosen because it is the dominant grass of the Vermejo shortgrass steppe and is important forage for both bison (Peden et al. 1974, Reynolds et al. 2003) and black-tailed prairie dogs (Fagerstone et al. 1981; also see Detling 2006a for review). The early and mid growing season collection times were on either end of the bison surveys, whereas late season grass samples were collected one month after bison surveys were complete. We obtained 40 samples (20 on- and 20 off-colony) during each collection period, for a total of 120 samples. However, one pair was not included in analyses because of misidentification of blue grama. Six more pairs were not included because seed heads were present in 5 off-colony and 1 on-colony samples; seed heads have different $\mathrm{N}$ concentrations and ADF values than shoots without seed (Peden et al. 1974).

Two-tailed paired $t$ tests were performed in program $\mathrm{R}$ to determine whether there were significant $(P<0.05)$ differences in crude protein and ADF in grass collected on and off prairie dog colonies. Data were assessed for normality at the $\alpha=0.10$ level, and Wilcoxon's signed-ranks tests were run when necessary.

\section{RESUlTS}

Bison

Bison of both sexes $(n=1037)$ strongly selected $(P<0.001$ in all cases $)$ for prairie dog colonies over uncolonized range, regardless of whether colonies occupied approximately a quarter (East) or half (West) of their pasture (Table 1, Fig. 1).

There were differences in frequencies of foraging on- and off-colony for both bulls and cows. A higher percentage of cows observed off-colony were grazing than those observed on-colony $\left(\chi^{2}\right.$ goodness-of-fit test, $\mathrm{df}=1$; West Pasture: $60 \%$ observed on-colony were grazing, $68 \%$ off-colony, $\chi^{2}=4.1, P=0.04$; East Pasture: $90 \%$ observed on-colony were grazing, $100 \%$ off-colony, $\chi^{2}=6.8, P=0.009$ ). There was no difference in frequency of grazing for bulls on- and off-colony in the West Pasture (44\% observed on-colony were grazing, $38 \%$ off-colony, $P=0.57$ ), but a higher percentage of bulls were observed grazing offcolony than on-colony in the East Pasture $\left(\chi^{2}\right.$ goodness of fit: $\mathrm{df}=1 ; 51 \%$ observed oncolony were grazing, $80 \%$ off-colony, $\chi^{2}=$ $34.5, P<0.001)$.

When preference for prairie dog colonies was assessed using a subset of data representing only those bison observed grazing during surveys ( $n=568$ of the total 1037 bison observed), there was still significant selection for prairie dog colonies $(P<0.004)$, with the exception of cows in the West Pasture $(P=0.16$; Table 2$)$. 
TABLE 2. Bison selection of black-tailed prairie dog colonies for those bison observed grazing $(n=568$ of 1037 total bison observed) on Vermejo Park Ranch, New Mexico. Locations of bison were obtained during driving surveys performed 26 May-28 June 2007.

\begin{tabular}{|c|c|c|c|c|c|}
\hline & $n$ & $\begin{array}{l}\% \text { Pasture } \\
\text { colonized }\end{array}$ & $\begin{array}{l}\% \text { Bison } \\
\text { on-colony }\end{array}$ & $\chi^{2}(\mathrm{df}=1)$ & $P$ \\
\hline \multicolumn{6}{|c|}{ West Pasture } \\
\hline Bulls & 44 & 48.5 & 77.3 & 14.6 & 0.001 \\
\hline Cows & 202 & 48.5 & 53.5 & 2.0 & 0.16 \\
\hline Total & 246 & 48.5 & 57.7 & 8.4 & 0.004 \\
\hline \multicolumn{6}{|c|}{ East Pasture } \\
\hline Bulls & 190 & 25.5 & 53.7 & 79.4 & $<0.001$ \\
\hline Cows & 132 & 25.5 & 53.8 & 55.6 & $<0.001$ \\
\hline Total & 322 & 25.5 & 53.7 & 135.0 & $<0.001$ \\
\hline
\end{tabular}

TABLE 3. Average distances in meters (SE) from bison observed on- and off-colony to the nearest water source on Vermejo Park Ranch, New Mexico, in summer 2007. Bold italicized numbers are significantly $(P<0.05)$ shorter distances based on Wilcoxon's rank-sum tests $(W)$.

\begin{tabular}{|c|c|c|c|c|c|c|}
\hline & \multicolumn{2}{|c|}{ Off-colony } & \multicolumn{2}{|c|}{ On-colony } & \multirow[b]{2}{*}{$W$} & \multirow[b]{2}{*}{$P$} \\
\hline & $n$ & Distance & $n$ & Distance & & \\
\hline \multicolumn{7}{|c|}{ West Pasture } \\
\hline Bulls & 26 & $481(60)$ & 171 & $374(7)$ & 2053 & 0.47 \\
\hline Cows & 170 & $577(15)$ & 263 & $365(7)$ & 6832 & $<0.001$ \\
\hline Total & 196 & $564(16)$ & 434 & $368(5)$ & 15113 & $<0.001$ \\
\hline \multicolumn{7}{|c|}{ East Pasture } \\
\hline Bulls & 101 & $615(41)$ & 166 & $539(25)$ & 7613 & 0.21 \\
\hline Cows & 79 & 349 (57) & 61 & $570(20)$ & 3664 & $<0.001$ \\
\hline Total & 180 & $515(35)$ & 227 & $549(18)$ & 22577 & 0.02 \\
\hline
\end{tabular}
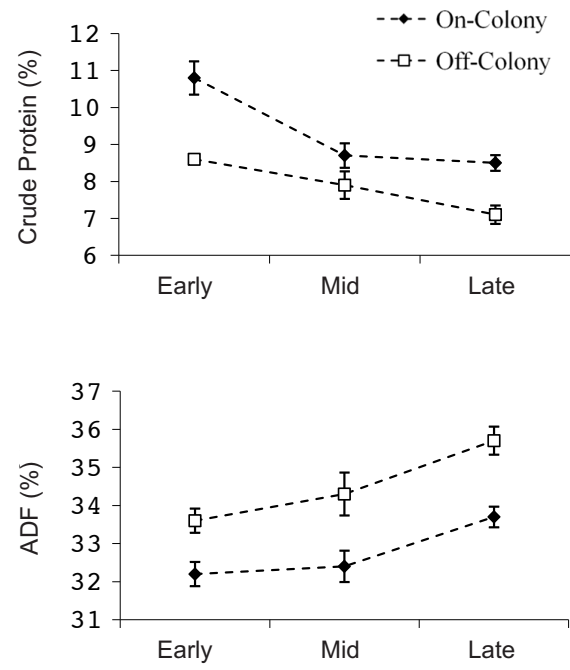

Fig. 2. Percent crude protein and percent acid detergent fiber (ADF) for blue grama collected on and off prairie dog colonies by period of the 2007 growing season (early [24 May-1 June], $n=19$ pairs; mid [24 June2 July], $n=19$ pairs; late [20-28 August], $n=15$ pairs) at Vermejo Park Ranch, New Mexico. All differences between on- and off-colony values were significant (paired $t$ tests and Wilcoxon's signed-ranks tests, $P<0.03$ ). Error bars represent one standard error around the mean.
Trends in distance between bison observed and the nearest water source varied by pasture and sex (Table 3). Cows on colonies in the West Pasture were closer to water, whereas cows off colonies in the East Pasture were closer to water (Table 3). No significant differences were detected in distance to water for bulls on- and off-colony in either pasture (Table 3).

\section{Grass}

Crude protein was higher $(n=53$ pairs; Wilcoxon's signed-ranks test: $V=1319, P<$ $0.001)$ and ADF concentrations were lower (paired $t$ test: $t=-6.5, P<0.001$ ) in blue grama on prairie dog colonies than off colonies (Fig. 2). Deconstructing the data by time of growing season (early, mid, late) did not affect interpretations (always $P \leq 0.03$ ).

\section{Discussion}

Our results of bison selecting for areas colonized by black-tailed prairie dogs on the Vermejo shortgrass steppe parallel preferences of bison (Coppock et al. 1983b, Krueger 1986) 
and cattle (Lomolino and Smith 2003) in mixedgrass and mixed-grass/shortgrass transitional ecosystems, respectively. Cattle in shortgrass systems also sometimes select for prairie dog colonies. During the growing season, Curtin (2008) found more cattle dung on than off prairie dog colonies in southern New Mexico, and Davidson et al. (2010) cite data on radiocollared cattle selection for prairie dog colonies in northern Mexico. While Guenther and Detling (2003) found that cattle in Colorado shortgrass steppe pastures did not consistently select for prairie dog colonies during the growing season of a relatively wet year, prairie dog colonies in some pastures were used at levels up to 4 times higher than expected based on availability. Collectively, these studies suggest that bison and cattle might select prairie dog colonies over uncolonized grassland across a broad array of grassland types in North America. As with many ecological phenomena, variation exists in the selection for prairie dog colonies by ungulates. For example, Green (1998) found that bison preference for colonized areas of northern mixed-grass prairie was only significant during a year of relatively high precipitation.

Competition between large ungulates and prairie dogs might be expected to be greater in pastures with a higher percentage of prairie dog colony coverage (i.e., pastures with lower total forage biomass per unit area; Derner et al. 2006). Bison selection for prairie dog colonies still existed at Vermejo in the pasture that was almost $50 \%$ covered by colonies (Table 1 ); however, cows observed grazing did not show a significant preference for prairie dog colonies in this pasture (Table 2). At Wind Cave National Park, South Dakota, bison selected for prairie dog colonies in a viewshed that was $12 \%$ prairie dog colonies (Coppock et al. 1983b, Krueger 1986, Green 1998). That bison selected for prairie dog colonies at the less productive Vermejo shortgrass site with proportionately greater prairie dog colony coverage supports other studies suggesting that competition between these herbivores is actually not strong (Uresk and Bjugstad 1983, Krueger 1986, Davidson et al. 2010).

Higher forage quality on Vermejo prairie dog colonies versus lower forage quality off colonies (Fig. 2) was not surprising given similar findings in other studies (Coppock et al. 1983a, Wydeven and Dahlgren 1985, Krueger 1986, Holland and Detling 1990, Cid et al.
1991, Green 1998, Fahnestock and Detling 2002, Cheng and Ritchie 2006). That a higher percentage of Vermejo bison observed offcolony were foraging than those observed oncolony ostensibly contradicts the concept of bison preferring to be on prairie dog colonies because of the superior grass quality available for grazing. Nevertheless, significant selection for on-colony habitat was found for all groups except for cows in the West Pasture when a subset of data that included only bison observed grazing was analyzed (Table 2 ).

Detling (2006a, 2006b) determined that graminoid biomass decreased by $28 \%$ in newly colonized areas of Wind Cave National Park, but the graminoid protein mass per unit area decreased only by $12 \%$ and the digestible dry matter by $23 \%$. No biomass measurements were obtained at Vermejo, but biomass differences on- and off-colony in shortgrass steppe are often not as drastic as in mixed-grass prairies (Weltzin et al. 1997, Winter et al. 2002, Hartley et al. 2009, Davidson et al. 2010). If biomass differences on- and off-colony are not as substantial in shortgrass steppe, and yet forage quality is higher on-colony, then it is possible that bison do not need to invest as much time foraging on-colony as off-colony, making it less likely to observe bison foraging on-colony. Perhaps this was the situation at Vermejo. Future investigation of graminoid biomass differences and bison diet on- and off-colony on shortgrass steppe might help explain why a higher proportion of bison were observed foraging off-colony than on-colony at Vermejo.

Distance to water sources was not expected to be a confounding factor in this study because 2007 was a relatively wet year at Vermejo, with water in ephemeral areas and multiple flowing rivers bisecting the viewshed. Data from the National Oceanic and Atmospheric Administration's National Climatic Data Center indicate that total rainfall in this area of New Mexico was $92 \mathrm{~mm}$ in May-June 2007, compared to a 1895-2012 average of $69 \mathrm{~mm}$ for this 2-month window (NOAA-NCDC 2012). Furthermore, the Palmer Drought Severity Index for May-June 2007 was + 1.40 (NOAANCDC 2012). At a finer scale, $80 \mathrm{~mm}$ was the average May-June total rainfall recorded at 2 independent weather stations located at either end of the Vermejo viewshed in 2007 (Vermejo Park Ranch unpublished data). However, it was necessary to ensure that bison were not 
simply utilizing water sources while their observed locations were being interpreted as selection for prairie dog colonies. Because trends in distances to water for bison on- and off-colony were not consistent between pastures and genders, we concluded that water sources did not substantially affect bison habitat use.

Furthermore, bison use of prairie dog colonies is less likely to be a coincidental finding of both bison and prairie dogs selecting the same habitat because all of the prairie dog colonies in the West Pasture viewshed, and most of the colonies in the East Pasture viewshed, were not naturally established but were instead created via translocations of prairie dogs (Long et al. 2006) as part of the ecological restoration of the Vermejo shortgrass steppe that commenced in 1999. Three prairie dog colonies in the West Pasture were extant during mapping of colony perimeters in 1997 (Dustin Long unpublished data), but suppression of poisoning and shooting caused expansion in colony areas of 3-, 8-, and 28-fold on these colonies by the time of this study. One colony in the West Pasture was naturally established in 2004, likely by prairie dogs dispersing from nearby colonies created via translocations. Further studies assessing bison use of prairie dog colonies before and after colony establishment might be insightful.

The results of this study should be applied with caution. Bison use of prairie dog colonies in shortgrass steppe needs to be examined over many years, seasons, and pastures before definitive conclusions are reached. This study was conducted in early summer, when differences in forage properties on- and off-colony (Detling and Whicker 1988, Fahnestock and Detling 2002) and bison selection for colonies (Coppock et al. 1983b, Wydeven and Dahlgren 1985, Krueger 1986) were greatest. Also, 2007 was a year of relatively high precipitation at Vermejo; Green (1998) suggested that selection of prairie dog colonies by bison is more likely during wet years. Furthermore, most prairie dog colonies at Vermejo were relatively young, and bison might select and graze older colonies less frequently than younger colonies (Coppock et al. 1983b). Bison observed at Vermejo were domestic; thus, their behavior might vary from the behavior of wild, free-roaming bison populations. Additionally, domestic bison vary genetically from pure bison lines. This variation also might alter behavior. However, this study does provide preliminary insight into bison use of prairie dog colonies on shortgrass steppe and suggests that the positive relationship between livestock and prairie dog colonies might not be as weak in semiarid shortgrass steppe as previously suspected (Guenther and Detling 2003).

\section{Management Implications}

The need to determine how livestock ranching is affected by the presence of prairie dog colonies in pastures across western North America is pressing. Generally, ranchers prefer to reduce the coverage of prairie dogs in their pastures because of potential competition for forage (Merriam 1902, Derner et al. 2006) and the possibility of livestock injuring themselves in prairie dog burrows (see Hoogland 1995). However, prairie dogs now occupy only $\sim 2 \%$ of their historic range due to lethal control, habitat alteration, and plague (Miller et al. 1994, Lockhart et al. 2006). Furthermore, the federally endangered black-footed ferret (Mustela nigripes L.) is virtually entirely dependent on prairie dog colonies for survival (Biggins et al. 2006), and a number of other species depend on these colonies to a large extent (Kotliar et al. 1999). Given these pressures, the disparity between the ranching and the conservation perspectives on prairie dogs is likely to remain and perhaps intensify.

More studies are needed to further understand interactions between domestic livestock and prairie dogs. The quality of blue grama, a major forage item for both prairie dogs and bison, was greater on than off prairie dog colonies. At least during a wet year (2007), and given relatively young prairie dog colonies, bison at Vermejo preferred to graze in areas of rangeland inhabited by prairie dogs. These findings, combined with the demonstrated preference of several ungulates for prairie dog colonies in multiple other studies, suggest that conserving the ecological function of prairie dogs in North American grasslands does not necessitate the exclusion of livestock from the landscape.

\section{ACKNOWLEDGMENTS}

We dedicate this paper to the late Joe Truett, whose encouragement and guidance were instrumental in conducting and completing this 
study. We thank Dustin Long, Turner Endangered Species Fund biologist, for his constant support and assistance at the ranch. Turner Enterprises, Inc. staff at Vermejo Park Ranch were also of great help. Financial support for this work was provided by the Turner Endangered Species Fund.

\section{Literature Cited}

Biggins, D.E., J.L. Godbey, M.R. Matchett, and T.M. LIVIERI. 2006. Habitat preferences and intraspecific competition in black-footed ferrets. Pages 129-140 in J.E. Roelle, B.J. Miller, J.L. Godbey, and D.E. Biggins, editors, Recovery of the black-footed ferret: progress and continuing challenges. U.S. Geological Survey Scientific Investigations Report 2005-5293, Fort Collins, CO.

Cheng, E., And M.E. Ritchie. 2006. Impacts of simulated grazing on Utah prairie dogs (Cynomys parvidens) in a low productivity ecosystem. Oecologia 147:546-555.

Cid, M.S., J.K. Detling, A.D. Whicker, and M.A. BRIZUELA. 1991. Vegetational responses of a mixedgrass prairie site following exclusion of prairie dogs and bison. Journal of Range Management 44: $100-105$

Coppock, D.L., J.K. Detling, J.E. Ellis, And M.I. Dyer. 1983a. Plant-herbivore interactions in a North American mixed-grass prairie. I. Effects of black-tailed prairie dogs on intraseasonal aboveground plant biomass and nutrient dynamics and plant species diversity. Oecologia 56:1-9.

1983b. Plant-herbivore interactions in a North American mixed-grass prairie. II. Responses of bison to modification of vegetation by prairie dogs. Oecologia 56:10-15.

Curtin, C.G. 2008. Interactions between cattle, prairie dogs, and small mammals in a desert grassland. Pages 29-38 in C.G. Curtin, editor, Emergent properties of the interplay between climate, fire, and grazing in desert grasslands. Desert Plants, Volume 24. University of Arizona Press, Tucson, AZ.

Davidson, A.D., E. Ponce, D.C. Lightfoot, E.L. Frederickson, J.H. Brown, J. Cruzado, S.L. Brantley, R. Sierra-Corona, R. List, D. Toledo, and G. Ceballos. 2010. Rapid response of a grassland ecosystem to an experimental manipulation of a keystone rodent and domestic livestock. Ecology 91: 3189-3200.

Derner, J.D., J.K. Detling, and M.F. Antolin. 2006. Are livestock weight-gains affected by black-tailed prairie dogs? Frontiers in Ecology and the Environment 9:459-464.

DetLing, J.K. 2006a. Do prairie dogs compete with livestock? Pages 66-92 in J.L. Hoogland, editor, Conservation of the black-tailed prairie dog: saving North America's western grasslands. Island Press, Washington, DC.

2006b. Black-tailed prairie dog interactions with other herbivores: mediation via alterations of vegetation. Pages 111-118 in J.E. Roelle, B.J. Miller, J.L. Godbey, and D.E. Biggins, editors, Recovery of the black-footed ferret: progress and continuing challenges. U.S. Geological Survey Scientific Investigations Report 2005-5293, Fort Collins, CO.

Detling, J.K., and A.D. Whicker. 1988. Control of ecosystem processes by prairie dogs and other grassland herbivores. Pages 23-29 in D.W. Uresk, G.L. Schenbeck, and R. Cefkin, technical coordinators, Eighth Great Plains Wildlife Damage Control Workshop Proceedings. General Technical Report RM-154, USDA Forest Service, Rocky Mountain Forest and Range Experiment Station, Fort Collins, CO.

Fagerstone, K.A., H.P. Tietjen, and O. Williams. 1981. Seasonal variation in the diet of black-tailed prairie dogs. Journal of Mammalogy 62:820-824.

Fahnestock, J.T., and J.K. Detling. 2002. Bison-prairie dog-plant interactions in a North American mixedgrass prairie. Oecologia 132:86-95.

Green, R.A. 1998. Nitrogen distribution in a perennial grassland: the role of American bison. Master's thesis, Colorado State University, Fort Collins, CO.

Green, R.A., And J.K. Detling. 2000. Defoliationinduced enhancement of total aboveground nitrogen yield of grasses. Oikos 91:280-284.

Guenther, D.A., AND J.K. Detling. 2003. Observations of cattle use of prairie dog towns. Journal of Range Management 56:410-417.

Hartley, L.M., J.K. Detling, and L.T. Savage. 2009. Introduced plague lessens the effects of an herbivorous rodent on grassland vegetation. Journal of Applied Ecology 46:861-869.

Holland, E.A., AND J.K. Detling. 1990. Plant response to herbivory and belowground nitrogen cycling. Ecology 71:1040-1049.

Hoogland, J.L. 1995. Black-tailed prairie dog: social life of a burrowing mammal. University of Chicago Press, Chicago, IL.

Kotliar, N.B., B.W. Baker, A.D. Whicker, and G. Plumb. 1999. A critical review of assumptions about the prairie dog as a keystone species. Environmental Management 24:177-192.

Krueger, K. 1986. Feeding relationship among bison, pronghorn, and prairie dogs: an experimental analysis. Ecology 67:760-770.

Lockhart, J.M., E.T. Thorne, and D.R. Gober. 2006. A historical perspective on recovery of the blackfooted ferret and the biological and political challenges affecting its future. Pages 6-19 in J.E. Roelle, B.J. Miller, J.L. Godbey, and D.E. Biggins, editors, Recovery of the black-footed ferret: progress and continuing challenges. U.S. Geological Survey Scientific Investigations Report 2005-5293, Fort Collins, CO.

Lomolino, M.V., AND G.A. SMith. 2003. Terrestrial vertebrate communities at black-tailed prairie dog $(\mathrm{Cy}$ nomys ludovicianus) towns. Biological Conservation 115:89-100.

Long, D.H., K. Bly-Honness, J.C. Truett, and D.B. SEERY. 2006. Establishment of new prairie dog colonies by translocation. Pages 188-209 in J.L. Hoogland, editor, Conservation of the black-tailed prairie dog: saving North America's western grasslands. Island Press, Washington, DC.

LotT, D.F., and S.C. Minta. 1983. Random individual association and social group instability in American bison (Bison bison). Zeitschrift für Tierpsychologie 61:153-172.

McHugh, T. 1958. Social behavior of the American buffalo (Bison bison bison). Zoologica 43:1-40. 
Merriam, C.H. 1902. The prairie dog of the Great Plains. Pages 257-270 in Yearbook of the United States Department of Agriculture, 1901. U.S. Department of Agriculture, Washington, DC.

Miller, B., G. Ceballos, and R. Reading. 1994. The prairie dog and biotic diversity. Conservation Biology 8:677-681.

Miller, B., R. Reading, J. Hoogland, T. Clark, G. Ceballos, R. List, S. Forrest, L. Hanebury, P. Manzano, J. Pacheco, and D. Uresk. 2000. The role of prairie dogs as a keystone species: response to Stapp. Conservation Biology 14:318-321.

[NOAA-NCDC] National OCEANiC and ATMOSPheric Administration-National Climatic Data CenTER. 2012. Plot time series [online]. [Cited 12 December 2012.] Available from: http://www.ncdc.noaa .gov/temp-and-precip/time-series/.

Peden, D.G., G.M. Van Dyne, R.W. Rice, and R.M. Hansen. 1974. The trophic ecology of Bison bison L. on shortgrass plains. Journal of Applied Ecology 11:489-497.

Reynolds, H.W., C.C. Gates, and R.D. Glaholt. 2003. Bison. Pages 1009-1060 in G.A. Feldhamer, B.C. Thompson, and J.A. Chapman, editors, Wild mammals of North America: biology, management, and conservation. 2nd edition. Johns Hopkins University, Baltimore, MD.

Schuler, K.L, D.M. Leslie JR., J.H. ShaW, and E.J. MaICHAK. 2006. Temporal-spatial distribution of American bison (Bison bison) in a tallgrass prairie fire mosaic. Journal of Mammalogy 87:539-544.

Uresk, D.W., and A.J. BJugstad. 1983. Prairie dogs as ecosystem regulators on the northern High Plains. Pages 91-94 in C.L. Kucera, editor, Proceedings of the Seventh North American Prairie Conference. Southwest Missouri State University, Springfield, MO.

Van Vuren, D. 1983. Group dynamics and summer home range of bison in southern Utah. Journal of Mammalogy 64:329-332.

Weltzin, J.F., S.L. Dowhower, And R.K. Heitschmidt. 1997. Prairie dog effects on plant community structure in southern mixed-grass prairie. Southwestern Naturalist 42:251-258.

Whicker, A.D., And J.K. Detling. 1988. Ecological consequences of prairie dog disturbances. BioScience 38:778-785.

Winter, S.L., J.F. Cully JR., AND J.S. Pontius. 2002. Vegetation of prairie dog colonies and non-colonized short-grass prairie. Journal of Range Management 55:502-508.

Wydeven, A.P., AND R.B. DAhLgREN. 1985. Ungulate habitat relationships at Wind Cave National Park. Journal of Wildlife Management 49:805-813.

Recevied 13 June 2012 Accepted 13 February 2013 